\title{
Population genetic structure of a colonising, triploid weed, Hieracium lepidulum
}

\author{
H Chapman, B Robson and ML Pearson \\ Department of Plant and Microbial Sciences, University of Canterbury, PB 4800, Christchurch, New Zealand
}

\begin{abstract}
Understanding the breeding system and population genetic structure of invasive weed species is important for biocontrol, and contributes to our understanding of the evolutionary processes associated with invasions. Hieracium lepidulum is an invasive weed in New Zealand, colonising a diverse range of habitats including native Nothofagus forest, pine plantations, scrubland and tussock grassland. It is competing with native subalpine and alpine grassland and herbfield vegetation. $H$. lepidulum is a triploid, diplosporous apomict, so theoretically all seed is clonal, and there is limited potential for the creation of variation through recombination. We used intersimple sequence repeats (ISSRs) to determine the population genetic structure of New Zealand populations of $H$. lepidulum. ISSR analysis of five populations from two
\end{abstract}

regions in the South Island demonstrated high intrapopulation genotypic diversity, and high interpopulation genetic structuring; $\Phi_{\mathrm{ST}}=0.54$ over all five populations. No private alleles were found in any of the five populations, and allelic differentiation was correlated to geographic distance. Cladistic compatibility analysis indicated that both recombination and mutation were important in the creation of genotypic diversity. Our data will contribute to any biocontrol program developed for $H$. lepidulum. It will also be a baseline data set for future comparisons of genetic structure during the course of $H$. lepidulum invasions.

Heredity (2004) 92, 182-188, advance online publication, 17 December 2003; doi:10.1038/sj.hdy.6800392

Keywords: apomixis; founder effect; invasion biology; recombination

\section{Introduction}

Understanding the breeding system and population genetic structure of invasive weed species is important for several reasons. In an applied sense, this knowledge is essential for biocontrol programs that involve hostspecific pathogens (Burdon and Marshall, 1981). More generally, population genetics contributes to our understanding of the evolutionary processes associated with past and present colonisation events (Barrett and Husband, 1990; Petit, 1997), and in the determination of the geographic origin of introduced species (Milne and Abbott, 2000). Molecular markers are also proving useful in identifying when inter- or even intraspecific hybridisation has played a role in the ability of a taxon to become invasive (for a review, see Ellstrand and Schierenbeck, 2000).

Several invasive taxa are obligate apomicts (Burdon and Marshall, 1981; Barrett, 1982), so that theoretically all their seed is clonal (Asker and Jerling, 1992). Lower levels of population genotypic diversity are predicted for them than for facultative apomicts or outcrossing taxa. Why then are they so successful? Is there any possibility for hybridisation? Perhaps in reality 'obligate' apomicts do not forgo recombination to the extent we currently assume, or certain types of mutation may lead to high levels of genotypic diversity.

Correspondence: H Chapman, School of Biological Sciences, University of Canterbury, PB 4800, Christchurch, New Zealand.

E-mail: h.chapman@botn.canterbury.ac.nz

Received 1 July 2002; accepted 19 September 2003
Diplosporous apomixis is a type of apomixis in which the gametophyte arises directly from an unreduced megaspore with no meiotic division, making the possibility of any sexual reproduction extremely unlikely (Asker and Jerling, 1992). Recent studies on triploid diplosporous species of the dandelion Taraxacum have pointed towards meiotic recombination as being prevalent in this genus. Character compatibility analyses of AFLP data have indicated that both recombination and mutation within clones is responsible for variation in some populations (Brookfield, 1992; van der Hulst et al, 2000; Mes et al, 2002). A detailed cytological study of triploid Taraxacum officinale by van Baarlen et al (2000) has demonstrated both low levels of outcrossing, and a mechanism for 'subsexual' recombination in this species. Subsexual reproduction is confined to diplosporous apomicts, and occurs when asynapsis is incomplete, so that occasional bivalent formation and crossing over occurs (Asker and Jerling, 1992).

Hieracium lepidulum (Stenstroem) Omang (Asteraceae) is a triploid, diplosporous apomict (Gadella, 1972). It differs from Taraxacum in that no sexual diploids have ever been recorded, so intraspecific hybridisation seems even more unlikely.

H. lepidulum is native to Northern and Central Europe, where it is typically a component of subalpine and alpine meadows, often in association with other Hieracium species. It has been recognised as an invasive weed in New Zealand since the 1990s. It is unprecedented in the diversity of habitats it colonises, including waste ground, Nothofagus (southern beech) forest, pine forest, and subalpine and alpine grassland (Connor, 1992; Duncan et al, 1997; Wiser et al, 1998). It is the first adventive weed 
to seriously threaten New Zealand alpine habitats, currently forming dense meadows at altitudes of $750 \mathrm{~m}$ and thriving at altitudes up to $1700 \mathrm{~m}$.

New Zealand populations of H. lepidulum have spread from relatively few founder populations. Seed probably arrived as contaminate of imported European grass seed during the late 1800s. Its subsequent invasion of diverse habitats is therefore surprising, given that the main mechanism for the creation of genotypic variation in obligate apomicts is generally considered to be mutation.

We had two goals in this study. First, we wanted to measure the magnitude of genotypic diversity within and between New Zealand populations of H. lepidulum, to provide information to underpin any strategy for biocontrol. Secondly, we wanted to provide baseline data for future comparisons during the course of H. lepidulum invasions, and for comparisons between New Zealand and native European populations. We plan to determine the population genetic consequences of colonisation in this triploid apomict.

We used intersimple sequence repeat (ISSR) technology, flow cytometry and character compatibility analysis to answer these questions. We chose to use ISSRs (Zietkiewicz et al, 1994) because they have already been shown to generate sufficient markers to easily identify genotypic diversity in clonal plants (Hollingsworth et al, 1998; Chapman et al, 2000). The incorporation of strategies to minimise the effects of dominance (for a review, see Sales et al, 2001) allow the estimation of $F_{\mathrm{ST}}$ values from dominant markers that are concordant with codominant allozyme markers (Aagaard et al, 1998; Jenczewski et al, 1999). The cladistic approach of character compatibility analysis is the most appropriate analysis presently available to distinguish between recombination and mutation in clonal polyploids (Mes, 1998).

\section{Methods}

\section{Sampling}

H. lepidulum is most common in the South Island of New Zealand, and especially in the Central Otago and Canterbury regions. Collections were made from each of five sites, three from Central Otago and two from Canterbury (Figure 1). The sites were chosen to include well-established, large populations and small populations. They included a range of altitudes (390-1700 m), and a range of habitats (alpine grassland to Nothofagus forest). The Pisa $(1700 \mathrm{~m})$ and Lochar Burn $(390 \mathrm{~m})$ sites were at either end of a $3 \mathrm{~km}$ transect that followed a boundary fence from the top to the lower slopes of the Pisa range. More site details are presented in Table 1. At each site, 10 individuals were dug up and transplanted to the glasshouse at the University of Canterbury for flow cytometry, and leaves from each of 20 other individuals were collected and dried in silica gel for DNA analysis. Plants collected were always at least $2 \mathrm{~m}$ from each other, to reduce the chances of sampling ramets from the same vegetative clone. Voucher specimens from each site are held in the University of Canterbury herbarium.

\section{Confirmation of apomixis}

To confirm apomixis, the upper half of six capitulum buds from each of the five populations were cut off with

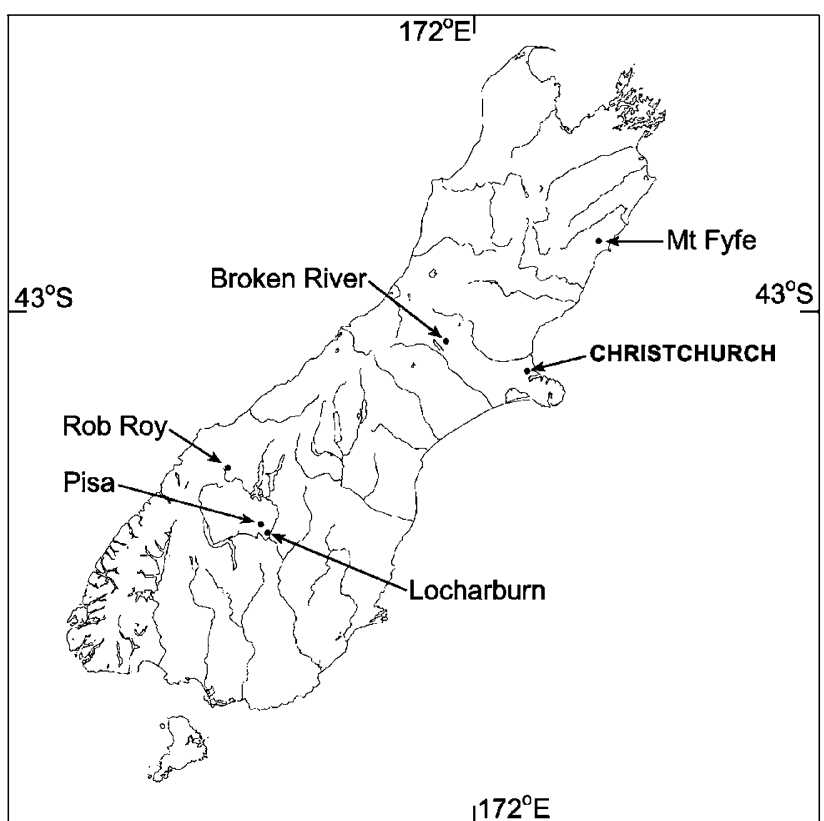

Figure 1 Location of the $H$. lepidulum populations used in this study.

a sharp blade just before opening in early autumn (March). This removed the anthers and stigmas, and thus prevented pollination. The cut capitula were then covered with a muslin bag until mature seed was observed. All the seed was collected and each capitulum scored for total number of seed, and number of filled seed.

Chromosome counts and flow cytometry

Chromosome counts were made on three individuals from Rob Roy, following the method of Krahulcová and Krahulec (1999), and these plants then served as standards for the flow cytometry measurements. Relative DNA content was determined for each of the 10 live plants from each population because a variation in DNA content of $3.7 \%$ or more (the contribution of a single chromosome to the genome) among individuals would demonstrate aneuploidy (Pfosser et al, 1995). For flow cytometry, isolation of nuclei from leaf tissue followed the method of Galbraith et al (1983) with some modifications. Punched discs of fresh leaf tissue $\left(24 \mathrm{~mm}^{2}\right)$ were placed together with the reference in a plastic Petri dish. A few drops of commercial nuclei isolation buffer, UV CyStain precise T solution A $(100 \mathrm{ml}$ deionised water, $2.1 \mathrm{~g}$ citric acid, $0.5 \mathrm{~g}$ Tween 20) (PARTEC $\mathrm{GmbH}$, Münster, Federal Republic of Germany) was added, and the tissue chopped finely with a stainless-steel razor blade. After approximately $90 \mathrm{~s}$, the sample was filtered through a $30 \mu \mathrm{m}$ filter, and $2.0 \mathrm{ml}$ of Partec Cystain Precise T solution B (100 ml deionised water, $7.9 \mathrm{~g}$ dibasic sodium phosphate, $0.5 \mathrm{ml}$ DAPI stock $455 \mu \mathrm{g} / \mathrm{ml}$ ) was added. Samples were then analysed for DNA content after at least $90 \mathrm{~s}$ of staining. For this, the Partec PA-II Particle Analysing System (PAS) was employed, using filter combinations of UG 1, TK420, TK590, and GG435, and a mercury arc lamp (HBO $100 \mathrm{~W} / 2)$. Our standard was a tetraploid $H$. pilosella. 
Table 1 Site details of the five H. lepidulum populations included in this study

\begin{tabular}{lcll}
\hline Site & Altitude $(m)$ & Age of population and density & Habitat \\
\hline Rob Roy & 1530 & Invading front; plants sparsely scattered & Chinochloa, Celmisia, Hebe, below glacier \\
Pisa & 1700 & $\begin{array}{l}\text { Invading front; common in sheltered areas, } \\
\text { sparsely scattered on windswept plateau }\end{array}$ & $\begin{array}{l}\text { Plateau of Pisa Range, sheltered from wind in the } \\
\text { escarpment lip }\end{array}$ \\
$\begin{array}{lll}\text { Lochar Burn } \\
\text { Broken River }\end{array}$ & 390 & $\begin{array}{l}\text { At least 15 years old; dense mat } \\
\text { Mecorded in the vicinity as 'rare' 1962a ; common }\end{array}$ & $\begin{array}{l}\text { Oversown pasture/H. lepidulum grassland } \\
\text { Mt Fyffe }\end{array}$ \\
\hline
\end{tabular}

${ }^{\mathrm{a} C o n n o r}$ (1962).

${ }^{\mathrm{b}} \mathrm{M}$ Morresy (personal observation).

Table 2 Summary of ISSR bands scored

\begin{tabular}{|c|c|c|c|}
\hline Primer & Primer sequence & No. of bands per primer & No. of polymorphic bands \\
\hline UBC900 & 5'-ACTTCCСCACAGGTTAACACA-3' & 7 & 7 \\
\hline UBC895 & 5'-AGAGTTGGTAGCTCTTGATC-3' & 7 & 5 \\
\hline UBC866 & $5^{\prime}-(\mathrm{CTC})^{6}-3^{\prime}$ & 7 & 7 \\
\hline UBC845 & 5'-СТСТСТСТСТСТСТCTRG-3' & 7 & 7 \\
\hline UBC822 & 5'-ТСТСТСТСТСТСТСТСА-3' & 7 & 7 \\
\hline UBC810 & 5'-GAGAGAGAGAGAGAGATG-3' & 6 & 3 \\
\hline
\end{tabular}

\section{ISSRs}

Fresh leaf tissue was used for total genomic DNA isolation. In total, $0.10-0.15 \mathrm{~g}$ of leaf tissue was crushed in a mortar containing crushed glass and $500 \mathrm{ml}$ of isolation buffer (200 mM Tris-HCl ( $\mathrm{pH} 8.0), 250 \mathrm{mM}$ $\mathrm{NaCl}, 25 \mathrm{mM}$ EDTA, $0.5 \%$ sodium dodecyl sulphate (SDS) and $10 \mathrm{mM} \beta$-mercapthoethanol). The mixture was transferred to a $1.5 \mathrm{ml}$ microfuge tube and incubated at $65^{\circ} \mathrm{C}$ for $1 \mathrm{~h}$, then centrifuged at 12000 r.p.m. for $5 \mathrm{~min}$. The resulting supernatant was transferred to a clean microfuge tube and washed twice with chloroform:isoamyl alcohol $(24: 1 \mathrm{v} / \mathrm{v})$. At each wash, the mixture was centrifuged for $5 \mathrm{~min}$ at 10000 r.p.m. The aqueous phase was transferred to a clean microfuge tube to which $300 \mu \mathrm{l}$ of cold isopropanol was added. The mixture was incubated at $-20^{\circ} \mathrm{C}$ for $20 \mathrm{~min}$ for DNA precipitation. The DNA was pelleted by centrifuging at 12000 r.p.m. for 5 min, washed with $70 \%$ ethanol, spun at 10000 r.p.m. for $3 \mathrm{~min}$, air-dried for $3 \mathrm{~min}$ and resuspended in $50 \mu \mathrm{l}$ of TE (tris acetate; $10 \mathrm{mM}$ Tris- $\mathrm{HCl}$ (pH 8.0), $1 \mathrm{mM}$ EDTA). The ISSR primers were supplied from the University of British Columbia Biotechnology Laboratory as primer set 9. They were amplified by the modified PCR procedure of Williams et al (1990). Six ISSR primers were screened over 20 samples. PCR was performed in a $25 \mu$ l reaction mixture per sample $(1 \times$ Taq polymerase PCR buffer, $400 \mu \mathrm{M}$ dNTPs, $6 \mathrm{mM}$ magnesium chloride, $0.2 \mu \mathrm{M}$ of primer, $2.5 \mathrm{U}$ of Taq DNA polymerase (Roche) and $100 \mathrm{ng}$ of genomic DNA). The amplification was performed in a PTC-200 Thermal Cycler (MJ Research). Initial denaturation was for $4 \mathrm{~min}$ at $94^{\circ} \mathrm{C}$, followed by 40 cycles of $90 \mathrm{~s}$ at $94^{\circ} \mathrm{C}, 30 \mathrm{~s}$ at $48^{\circ} \mathrm{C}, 60 \mathrm{~s}$ at $72^{\circ} \mathrm{C}$, and a final extension of $4 \mathrm{~min}$ at $72^{\circ} \mathrm{C}$. The PCR products were separated electrophoretically on $2 \%$ agarose gels in $1 \times$ TAE buffer and stained with ethidium bromide. The presence or absence of bands was scored under UV illumination. Six primers (Table 2) that gave clear and consistent banding patterns for the analysis of the complete sample set were selected. Duplicates were run for all primer/individual plant combinations, and a negative control included in each gel. From this, bands were scored based on their reproducibility and consistency, to determine the ISSR phenotype for each individual sampled. Only bands that were clear and reproducible were included in the analysis.

\section{Data analysis}

The interpretation of allele frequency data of dominant markers must be approached with caution, because statistical methods are based on assumptions of HardyWeinberg equilibrium (Lynch and Milligan, 1994). To overcome this, we have used the phenetic analysis of molecular variance (AMOVA) (Excoffier et al, 1992), which makes no assumptions about Mendelian gene frequencies. AMOVA is based on the analysis of pairwise genetic distances, using the Euclidean distance measure (Excoffier et al, 1992) to estimate variance components for the ISSR phenotypes. Variation was partitioned among individuals/within populations, among populations/ within regions, and among regions. The resulting coefficients of subdivision, $\Phi_{\mathrm{ST}}, \Phi_{\mathrm{SC}}, \Phi_{\mathrm{CT}}$ are analogous to Wright's (1965) $F_{\mathrm{ST}}$ statistics, but they differ in their assumptions of heterozygosity. $\Phi_{\mathrm{ST}}$ was also calculated for among-site variance among each pair of Otago sites and the two Canterbury sites. Significance values were assigned to variance components on the basis of a set of null distributions generated by a permutation process that draws 1000 individual samples from the raw matrix and randomly assigns individuals to one of the six populations (Excoffier et al, 1992). AMOVA is now routinely used in the analysis of RAPD and ISSR data (Huff et al, 1998; Bartish et al, 1999). Multivariate cluster analysis and principal coordinate analysis (PCO), using the program MVSP version 3.1 (Kovach Computing Services Pentraeth, UK, 1998), were used to visualise the data. PCO is an ordination method similar to principal component analysis, except that it uses the distance matrix, rather than the values, to plot the axes (Manly, 1994). A UPMGA dendrogram, based on Nei's (1972) similarity matrix was used to illustrate the relationships among all the 89 individuals from each of the five sites. 
Nei's (1972) measure of genetic distance is an appropriate one for ISSR data as only shared presence of bands is used to calculate similarity. Spatial representation of relative similarities among individuals was provided by the PCO.

A Mantel test was carried out to determine if there was a significant correlation between genetic distance (Nei, 1972) and geographic distance $(\mathrm{km})$, using the program 'Tools for Population Genetic Analyses' (TFPGA) (Miller, 1997). We did not seek to estimate values of gene flow because Slatkin's (1985) estimate assumes that populations are at an equilibrium for migration and drift, and that there has been sufficient time for mutation to have generated new alleles in populations.

In order to determine if intrapopulation genotypic variation was due to mutation within a single clone or the result of recombination (Brookfield, 1992), we used the cladistic approach of character compatibility analysis (Mes, 1998). This technique is used to determine if differences between pairs of genotypes, as measured by differences in dominant markers, are more parsimoniously explained by mutation or by recombination. For example, in a comparison of potential patterns in pairwise, binary characters generated only by mutation, only three of the four possible combinations of characters can be achieved in a lineage, excluding the presence of back mutations. So that if all four possible character combinations are present, this is an incompatibility, and can be explained by recombination. Such incompatible character state occurrences can be used as an indication of both recombination (the number of genotypes removed from a data set to produce compatibility), and mutation (the number of compatible genotypes) when summed over the whole data matrix (Mes, 1998; van der Hulst et al, 2000). Compatibility analysis is suitable for the analysis of dominant molecular data in polyploids because allelic interpretation is not necessary. We used the program Phylogenetic Inference by Compatibility Analysis (PICA) version 4.0 (Wilkinson, 2001) for our analysis.

\section{Results}

\section{Confirmation of apomixis}

All of the 10 individuals from each of the five populations spontaneously set seed in the glasshouse, as did the 30 emascualted capitula. The average number of seed produced per emascualted capitulum was 49.1, SD 6.8 (range $=40-65$ ), and the average percent filled seed was 95, SD 2.4 (range $=100-91 \%$ ).

All 10 individuals from each of four sites Pisa, Lochar Burn, Rob Roy and Mt Fyffe had DNA contents that were between 1 and 1.2 times the amount of DNA of the standard triploid Rob Roy plant, which indicated that they were all triploid.

\section{Genetic diversity}

The six ISSR primers produced a total of 41 clear and reproducible bands, $36(88 \%)$ of which were polymorphic (Table 2). No private bands were recorded from any of the populations. The number of polymorphic bands varied between 24 at Mt Fyffe and 13 at Broken River (Table 3).

Cluster analysis (Figure 2) on all five populations revealed one main cluster with $75 \%$ similarity to a small cluster comprising only individuals from Mt Fyffe. Furthermore, individuals within each population were clustered, so that except for a few exceptions (Figure 2) each population had its own node. Three Lochar Burn individuals fall within the predominantly Pisa cluster,

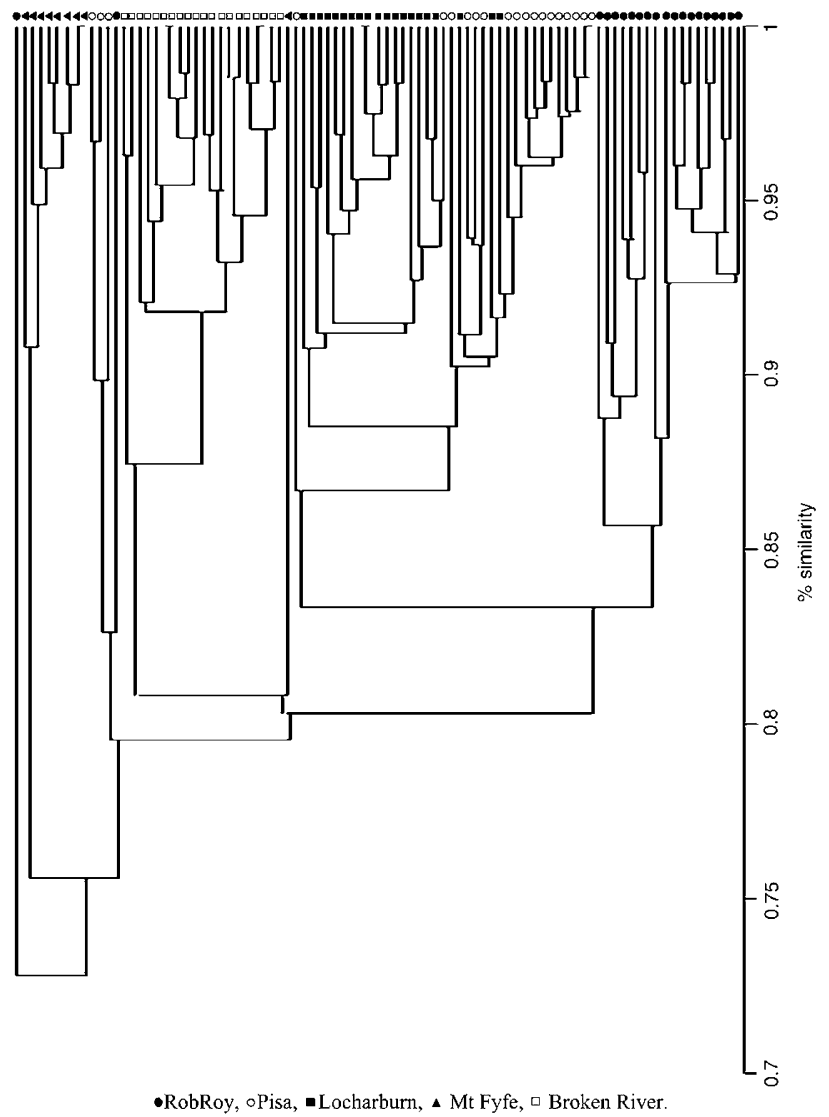

Figure 2 UPGMA dendrogram depicting patterns of genetic similarity by 41 ISSR fragments and 89 individuals of $H$. lepidulum from the five populations included in this study.

Table 3 Summary of band characters in five populations of $H$. lepidulum resulting from six ISSR primers

\begin{tabular}{lcccrrr}
\hline Site & Rob Roy & Pisa & Lochar Burn & Broken River & Mt Fyffe & All \\
\hline Total no. of bands & 39 & 40 & 39 & 39 & 41 \\
No. fixed & 18 & 21 & 20 & 26 & 13 \\
No. variable & 21 & 19 & 19 & 0 & 51 \\
No. unique & 0 & 0 & 49 & 33 & 0 & 0 \\
\% variable & 57 & 47 & 04 & 59 & 88 \\
\hline
\end{tabular}


and a Rob Roy individual is closely related to individuals from Broken River.

Most individuals differed in their ISSR phenotype, which we refer to as genotype in the rest of this paper. Every individual sampled from the invading front below the Rob Roy glacier was genotypically unique. Only two individuals shared the same genotype from the Pisa population and similarly only a single shared genotype was recorded from each of the Lochar Burn and Mt Fyffe populations. The plants from Broken River comprised 16 unique genotypes and two shared ones (Figure 2). Patterns of genetic similarities among genotypes in all of the five populations were similar, with most genotypes being $90 \%$ or more similar, although at Rob Roy several genotypes were $89-87 \%$ similar.

Ordination analysis complimented the cluster analysis by providing spatial representation of relative similarities among individuals (Figure 3 ). The two-dimensional PCO plot clearly differentiates the Otago and Canterbury sites, and, with one exception, the Broken River and Mt Fyffe sites. Individuals from the three Otago sites, clustering towards the left of the PCO plot, are less distinct, with individuals from the Pisa population scattered between the Lochar Burn and Rob Roy population clusters. Axis 1 explained $22.8 \%$ of the variation, and Axis 2, $12.6 \%$.

The apparent patterns revealed by clustering and ordination analysis were analysed by AMOVA (Table 4), which showed that almost half of the total ISSR variation $(46 \%)$ could be explained by variation within popula-

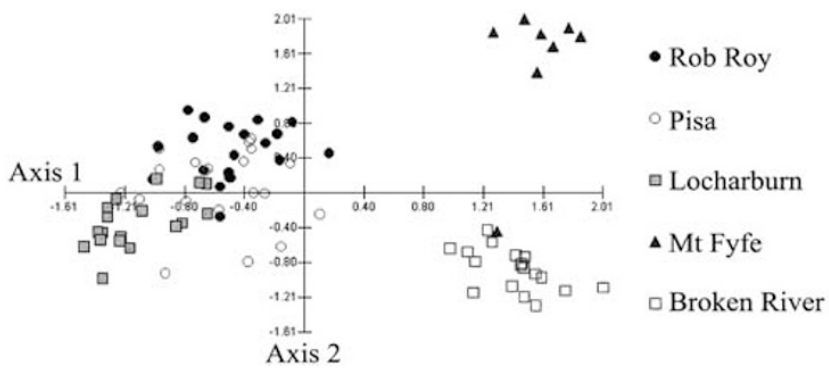

Figure 3 Principal coordinates plot of 41 ISSR fragments depicting patterns of relatedness and genetic variation among 89 individuals from five populations of $H$. lepidulum. tions, $31 \%$ by variation among the populations within regions and $22.8 \%$ among regions (Otago vs Canterbury). $\Phi_{\mathrm{ST}}$, analogous to Wright's (1965) $F_{\mathrm{ST}}$ statistic $=0.54$ $(P<0.001)$, which is indicative of high levels of genetic structuring and low levels of gene flow.

The results of the Mantel test to determine if there was a significant correlation between genetic distance (Nei, 1972) and geographic distance $(\mathrm{km})$ over the five sites was significant $(r=0.94)$.

All sites displayed considerable matrix incompatibility; total matrix incompatibility and its reduction upon successive deletion of genotypes for each site is presented in Figure 4. Although this type of analysis does not allow a precise estimation of the frequency of recombination (Mes, 1998), the fact that between 9 and 14 genotypes in all populations except Mt Fyffe had to be removed in order to gain compatibility is indicative of substantial recombination. The relatively few genotypes deleted from Mt Fyffe probably reflect its small sample size (van der Hulst et al, 2000).

\section{Discussion}

Genetic diversity in a triploid, invasive species

Our results indicate that $H$. lepidulum is primarily apomictic, with between 100 and $95 \%$ filled seed

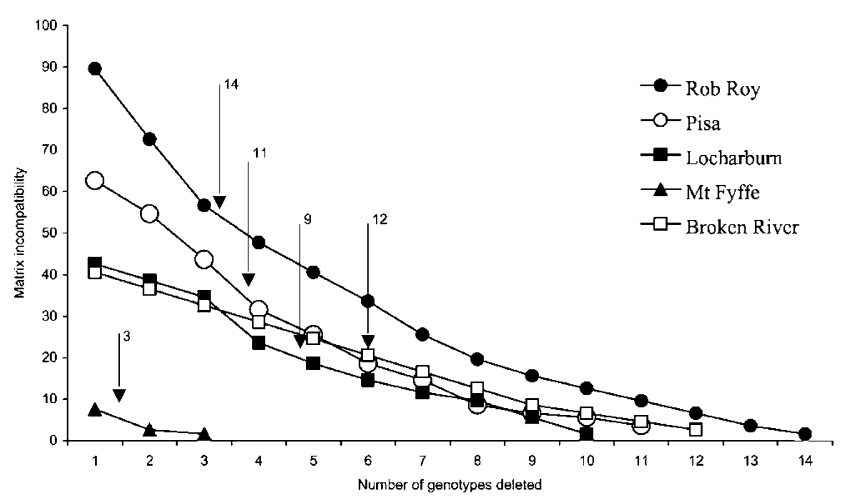

Figure 4 Reduction of matrix incompatibility upon successive deletion of ISSR genotypes in each of the five populations of $H$. lepidulum included in this study. The total number of genotypes and the number that needed to be deleted to eliminate incompatibility are given above each curve.

Table 4 Nested AMOVA for 89 individuals of H. lepidulum using 41 ISSR fragments

\begin{tabular}{|c|c|c|c|c|c|c|c|}
\hline Source of variation & $d f$ & $S S D$ & $M S D$ & Variance component & $\%$ Total & $\Phi$-stats & P-value \\
\hline Among regions (Otago and Canterbury) & 2 & 96.8 & 96.8 & 1.48 & 22.77 & $\Phi_{\mathrm{CT}} 0.23$ & $<0.001$ \\
\hline Among sites/within regions & 3 & 115.0 & 38.3 & 2.02 & 31.09 & $\Phi_{\mathrm{SC}} 0.40$ & $<0.001$ \\
\hline Among individuals/within populations & 84 & 252.3 & 3.0 & 3.00 & 46.14 & $\Phi_{\mathrm{ST}} 0.54$ & $<0.001$ \\
\hline \multicolumn{8}{|l|}{ Among sites in Otago } \\
\hline Pisa/Lochar Burn & 39 & 131.1 & 24.7 & 1.10 & 28.12 & $\Phi_{\mathrm{ST}} 0.28$ & $<0.001$ \\
\hline Pisa /Rob Roy & 39 & 165.6 & 37.6 & 1.71 & 33.72 & $\Phi_{\mathrm{ST}} 0.34$ & $<0.001$ \\
\hline Lochar Burn/Rob Roy & 39 & 165.0 & 47.6 & 2.23 & 41.90 & $\Phi_{\mathrm{ST}} 0.42$ & $<0.001$ \\
\hline \multicolumn{8}{|l|}{ Among sites in Canterbury } \\
\hline Broken River/Mt Fyffe & 28 & 118.2 & 45.8 & 3.42 & 56.42 & $\Phi_{\mathrm{ST}} 0.56$ & $<0.001$ \\
\hline
\end{tabular}

The total data set contains individuals from five sites and two regions: Rob Roy, Pisa, and Lochar Burn (Otago); Broken River, and Mt Fyffe (Canterbury). Statistics include sums of the squared deviations (SSDs), mean squared deviations (MSDs), variance component estimates, the percentage of the total variance (\% Total) contributed by each component, $\Phi$-statistics, and the probability $P$ of obtaining a more extreme component estimate by chance alone (estimated from 1000 sampling realisations). 
produced after emasculation. Whether the unfilled seed has simply aborted, or represent potential sexual seed, has not yet been determined. Crossing experiments are underway to elucidate this.

All five populations of $H$. lepidulum included in this analysis had high levels of genetic and genotypic diversity. Overall, the populations were highly structured. A $\Phi_{\mathrm{ST}}$ value over all five populations of 0.54 is high according to guidelines described by Hartl (2000), and indicative of low levels of gene flow. Less structuring was found among each pair of the Otago populations, but it was still high according to Hartl (2000). $\Phi_{\mathrm{ST}}=0.28$ for Pisa and Lochar Burn, and $\Phi_{\mathrm{ST}}=0.34$ and $\Phi_{\mathrm{ST}}=0.42$ for Rob Roy and Pisa, and Rob Roy and Lochar Burn, respectively. Such high differentiation between populations can be explained in a number of ways, including (i) a breeding system that hinders gene flow, (ii) founder populations, and (iii) selection.

The diplosporous type of apomixis must severely restrict gene flow among populations, even if it is higher than expected within populations. Character compatibility analysis (below) demonstrated that between $30 \%$ (Rob Roy) and 70\% (Mt Fyffe) of the variation within populations could be explained by mutation alone.

All New Zealand populations are founder populations in an evolutionary sense, as $H$. lepidulum was first recorded in New Zealand during the late 1880's. In this study the Lochar Burn population was the largest and most established, having been present in the area for at least 20 years and now covering many hectares of oversown tussock grassland. The Pisa population, at a higher altitude in the same range, is more recent and was probably a consequence of wind-blown seed from lower slopes. Its difference in allele frequencies from Lochar Burn can best be explained as a consequence of founder effect and drift. Alternatively, or in addition, selection may be acting to differentiate the populations because the Pisa site suffers a more extreme environment than the lower slopes of the Lochar Burn site.

The Rob Roy population is almost certainly a founder population, or 'invading front', a consequence of windblown seed from the H. lepidulum 'meadow' lower down the Rob Roy valley. It is very sparse, with individuals mostly confined to sheltered microsites such as holes in the ground or rocky outcrops.

The high $\Phi_{\mathrm{ST}}$ value of 0.56 for the Broken River and Mt Fyffe populations may be explained by a combination of breeding system, different source populations, and founder effect. Broken River is an established, large population, with individuals having been in the area since at least the early 1940s (herbarium records). $H$. lepidulum has been present along the Mt Fyffe track for at least 20 years (M Morresy, personal observation), but has not noticeably spread and is still confined to small patches along the track edge. Compatibility analysis (below) has shown that mutation rather than recombination could explain $70 \%$ of the genotypes found at $\mathrm{Mt}$ Fyffe, although this could be an overestimate because of the small population size. There was no evidence of increased genetic variation within large, invasive populations such as Lochar Burn, as compared with small noninvasive populations such as Mt Fyffe.

Character compatibility analysis showed that both recombination and mutation contributed to intrapopulation genotypic diversity, but suggested that most genotypes (except for Mt Fyffe) were the product of recombination. Mes (1998) points out that compatibility analysis is only a crude measure of recombination, but until a more accurate method is devised to distinguish between recombination and mutation, this estimate is the best measure available.

\section{Origins of variation}

An obvious question arising from this study is, given such high levels of variation, where does it come from? The possible sources are (i) recombination and outcrossing, (ii) subsexual reproduction (Asker and Jerling, 1992), (iii) somatic recombination through transposition, and (iv) other mutations.

Van Baarlen et al (2000) recently demonstrated occasional meiosis within the megasporocyte of Taraxacum officinale L., another diplosporous apomict. They also measured pollen viability, and concluded that amongapomict hybridisation could occur at a rate that in an evolutionary time frame' could generate considerable clonal diversity. The authors also point out that genetic variation can arise by autosegregation. This is a two-part process involving both chromosome gain and loss and subsexual reproduction. Our flow cytometry results showed no significant difference in DNA content among any of the 40 individuals from each of the four populations sampled, which indicates that the gain or loss of whole chromosomes is unlikely. Subsexual reproduction is the crossing over between a heterozygous locus and the centromere without reduction (van Baarlen et al, 2000). Van Baarlen et al (2000) explain as to why it is likely to result in more homozygosity, rather than increased genetic variation.

Somatic recombination, resulting from transposition (King and Schaal, 1990; Richards, 1996) leads to recombination throughout the genome. It is possible that some of the genotypes that were responsible for incompatibilities in our study were carrying the signature of somatic, rather than sexual, recombination.

While somatic mutation was obviously important in the creation of genetic variation within the H. lepidulum populations included in this study, recombination, most probably the result of low levels of outcrossing, was equally so.

In conclusion, New Zealand populations of H. lepidulum are genotypically diverse due to a combination of recombination and mutation. This breeding system makes the effective control of $H$. lepidulum by genotype-specific pathogens unlikely (Burdon and Marshall, 1981). However, population genetic variation is highly structured, indicative of low levels of gene flow among populations. Founder effect is the most likely explanation for allelic differentiation among populations; no private alleles were found in the loci surveyed in this investigation, and there was a positive correlation between genetic distance and geographic distance. Further investigations using genetic fitness measures, competition and common garden experiments will help elucidate the role of adaptation in population differentiation.

\section{Acknowledgements}

We thank Paul Roberts for help with the fieldwork, and John Aspinall of Aspiring, Geoff Brown of Lochar Burn, 
and Jackie McMillan of Pisa stations for permission to collect samples from their land. Financial assistance came from the Hellaby Indigenous Grassland Research Trust, The Department of Conservation, The Brian Mason Scientific and Technical Research Trust, and the University of Canterbury.

\section{References}

Aagaard J, Krutovskii K, Strauss S (1998). RAPDs and allozymes exhibit similar levels of diversity and differentiation among populations and races of Douglas-fir. Heredity 81: 69-78.

Asker SE, Jerling L (1992). Apomixis in Plants, CRC Press: Boca Raton, FL.

Barrett SCH (1982). Genetic variation in weeds. In: Charwdattan R, Walker HL (eds) Biological Control of Weeds with Plant Pathogens, John Wiley: New York pp 73-99.

Barrett SCH, Husband BC (1990). The genetics of plants migration and colonization. In: Brown AHD, Clegg MT, Kahler AL, Weir BS (eds) Plant Population Genetics, Breeding and Genetic Resources, Sinauer Associates: Sunderland, MA pp 254-277.

Bartish IV, Jeppson N, Nybom H (1999). Population genetic structure in the dioecious pioneer plant species Hippophae rhamnoides investigated by random amplified polymorphic DNA (RAPD) markers. Mol Ecol 8: 791-802.

Brookfield J (1992). DNA fingerprinting in clonal organisms. Mol Ecol 1: 21-26.

Burdon JJ, Marshall DR (1981). Biological control and the reproductive mode of weeds. J Appl Ecol 18: 649-658.

Chapman HM, Parh D, Oraguzie N (2000). Genetic structure and colonising success of a clonal weedy species, Pilosella officinarum (Asteraceae). Heredity 84: 401-409.

Connor HE (1992). Hawkweeds, Hieracium spp., in tussock grasslands of Canterbury, New Zealand, in 1960s. NZ J Bot 30: $247-261$.

Duncan R, Colhoun KM, Foran B (1997). The distribution and abundance of Hieracium species (Hawkweeds) in the dry grasslands of Canterbury and Otago. NZ J Ecol 21: 51-62.

Ellstrand NC, Schierenbeck KA (2000). Hybridization as a stimulus for the evolution of invasiveness in plants? Proc Natl Acad Sci USA 97: 7043-7050.

Excoffier L, Smouse PE, Quattro JM (1992). Analysis of molecular variance inferred from metric distances among DNA haplotypes: application to human mitochondrial DNA restriction data. Genetics 131: 479-491.

Gadella TWJ (1972). Biosystematic studies in Hieracium pilosella L. and some related species in the sub genus Pilosella. Bot Notiser 125: 25-369.

Galbraith DW, Harkins KR, Maddox JM, Ayres NM, Sharma DP, Firoozabady E (1983). Rapid flow cytometric analysis of the cell cycle in intact plant tissues. Science 220: 1049-1051.

Hartl D (2000). A Primer for Population Genetics, Sinauer Associates Inc.: Sunderland, MA.

Hollingsworth M, Hollingsworth P, Jenkins G, Bailey J, Ferris C (1998). The use of molecular markers to study patterns of genotypic diversity in some invasive alien Fallopia spp. (Polygonaceae). Mol Ecol 7: 1681-1691.

Huff DR, Quinn JA, Higgins B, Palazzo AJ (1998). Random amplified polymorphic DNA (RAPD) variation among native little bluestem Schizachyrium scoparium (Michx.) Nash. populations from sites of high and low fertility in forest and grassland biomes. Mol Ecol 7: 1591-1597.

Jenczewski E, Prosperi J, Ronfort J (1999). Differentiation between natural and cultivated populations of Medicago sativa (Leguminosae) from Spain: analysis with random amplified polymorphic DNA (RAPD) markers and comparison to allozymes. Mol Ecol 8: 1317-1330.
King LM, Schaal BA (1990). Genotypic variation within asexual lineages of Taraxacum officinale. Proc Natl Acad Sci USA 87: 998-1002.

Krahulcová A, Krahulec F (1999). Chromosome numbers and reproductive systems in selected representatives of Hieracium subgenus pilosella in the Krkonoše Mts (the Sudeten Mts). Preslia 71: 217-234.

Lynch M, Milligan BG (1994). Analysis of population genetic structure with RAPD markers. Mol Ecol 3: 91-99.

Manly B (1994). Multivariate Statistical Methods: A Primer, 2nd edn. Chapman \& Hall: London.

Mes T (1998). Character compatibility of molecular markers to distinguish asexual and sexual reproduction. Mol Ecol 7: 1719-1727.

Mes T, Kuperus P, Kirschner J, Stepanek J, Storchova H, Oosterveld P, Den Nijs J (2002). Detection of genetically divergent clone mates in apomictic dandelions. Mol Ecol 11: 253-265.

Miller M (1997). Tools for population genetic analysis (TFPGA) 1.3: A windows program for the analysis of allozyme and molecular population data. Computer software distributed by author. Department of Biological Sciences, Northern Arizona University.

Milne R, Abbott R (2000). Origin and evolution of invasive naturalized material of Rhododendron ponticum $\mathrm{L}$. in the British Isles. Mol Ecol 9: 541-556.

Nei M (1972). Genetic distance between populations. Am Nat 106: 283-292.

Petit RJ (1997). Chloroplast DNA footprints of postglacial recolonization by oaks. Proc Natl Acad Sci USA 94: 9996-10001.

Pfosser M, Amon A, Lelley T, Heberle-Bors E (1995). Evaluation of sensitivity of flow cytometry in detecting aneuploidy in wheat using disomic and ditelosomic wheat-rye addition lines. Cytometry 21: 387-393.

Richards AJ (1996). Genetic variability in obligate apomicts of the genus Taraxacum. Folia Geobot Phytotaxon 31: 405-414.

Sales E, Nebauer S, Mus M, Segura J (2001). Population genetic study in the Balearic endemic plant species Digitalis minor (Scrophulariaceae) using RAPD markers. Am J Bot 88: 1750-1759.

Slatkin M (1985). Rare alleles as indicators of gene flow. Evolution 39: 53-65.

van Baarlen P, van Dijk P, Hoekstra RF, de Jong JH (2000). Meiotic recombination in sexual diploid and apomictic triploid dandelions (Taraxacum officinale L.). Genome 43: 827-835.

van der Hulst R, Mes T, den Nijs J, Bachmann K (2000). Amplified fragment length polymorphism (AFLP) markers reveal that population structure of triploid dandelions (Taraxacum officinale) exhibits both clonality and recombination. Mol Ecol 9: 1-8.

Wilkinson M (2001). PICA 4.0: Software and Documentation, Department of Zoology, The Natural History Museum: London.

Williams JGK, Kubelik AR, Livak KJ, Rafalski JA, Tingey SV (1990). DNA polymorphisms amplified by arbitrary primers are useful as genetic markers. Nucleic Acids Res 18: 6231-6235.

Wiser SK, Allen RB, Clinton PW, Platt KH (1998). Community structure and forest invasion by an exotic herb over 23 years. Ecology 79: 2071-2081.

Wright S (1965). The interpretation of population structure by Fstatistics with special regard to systems of mating. Evolution 19: 394-420.

Zietkiewicz E, Rafalski A, Labuda D (1994). Genome fingerprinting by simple sequence repeats (SSR) - anchored polymerase chain reaction amplification. Genomics 20: 176-183. 